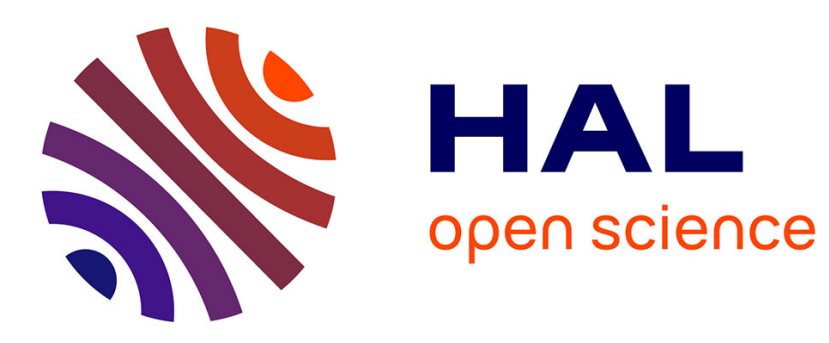

\title{
Avian Mycobacteriosis in Companion Birds: 20-Year Survey
}

Giovanni Manarolla, Emmanouil Liandris, Giuliano Pisoni, Davide Sassera, Veterinary Biotechnology, Guido Grilli, Animal Science, Daniele Gallazzi, Giuseppe Sironi, Paolo Moroni, et al.

\section{To cite this version:}

Giovanni Manarolla, Emmanouil Liandris, Giuliano Pisoni, Davide Sassera, Veterinary Biotechnology, et al.. Avian Mycobacteriosis in Companion Birds: 20-Year Survey. Veterinary Microbiology, 2009, 133 (4), pp.323. 10.1016/j.vetmic.2008.07.017 . hal-00532457

\section{HAL Id: hal-00532457 https://hal.science/hal-00532457}

Submitted on 4 Nov 2010

HAL is a multi-disciplinary open access archive for the deposit and dissemination of scientific research documents, whether they are published or not. The documents may come from teaching and research institutions in France or abroad, or from public or private research centers.
L'archive ouverte pluridisciplinaire HAL, est destinée au dépôt et à la diffusion de documents scientifiques de niveau recherche, publiés ou non, émanant des établissements d'enseignement et de recherche français ou étrangers, des laboratoires publics ou privés. 


\section{Accepted Manuscript}

Title: Avian Mycobacteriosis in Companion Birds: 20-Year Survey

Authors: Giovanni Manarolla, Emmanouil Liandris, Giuliano Pisoni, Davide Sassera, Veterinary Biotechnology, Guido Grilli, Animal Science, Daniele Gallazzi, Giuseppe Sironi,

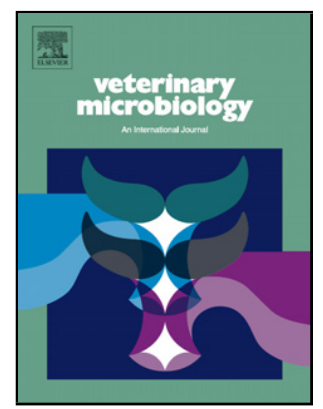
Paolo Moroni, Renata Piccinini, Animal Science, Tiziana Rampin

PII: S0378-1135(08)00288-5

DOI: doi:10.1016/j.vetmic.2008.07.017

Reference: VETMIC 4105

To appear in: $\quad$ VETMIC

Received date: $\quad 22-1-2008$

Revised date: $\quad$ 12-6-2008

Accepted date: $\quad 16-7-2008$

Please cite this article as: Manarolla, G., Liandris, E., Pisoni, G., Sassera, D., Biotechnology, V., Grilli, G., Science, A., Gallazzi, D., Sironi, G., Moroni, P., Piccinini, R., Science, A., Rampin, T., Avian Mycobacteriosis in Companion Birds: 20-Year Survey, Veterinary Microbiology (2007), doi:10.1016/j.vetmic.2008.07.017

This is a PDF file of an unedited manuscript that has been accepted for publication. As a service to our customers we are providing this early version of the manuscript. The manuscript will undergo copyediting, typesetting, and review of the resulting proof before it is published in its final form. Please note that during the production process errors may be discovered which could affect the content, and all legal disclaimers that apply to the journal pertain. 
1 Avian Mycobacteriosis in Companion Birds: 20-Year Survey

2 Giovanni Manarolla,${ }^{*}$ DVM, PhD, Emmanouil Liandris, $\dagger$ DVM, PhD, Giuliano

3 Pisoni,* DVM, PhD, Davide Sassera, ${ }^{*}$ MS Veterinary Biotechnology, PhD, Guido

4 Grilli, ${ }^{*}$ MS Animal Science, PhD, Daniele Gallazzi,* DVM, Giuseppe Sironi,* DVM,

5 PhD, Paolo Moroni, ${ }^{*}$ DVM, PhD, Renata Piccinini, ${ }^{*}$ MS Animal Science, Tiziana

6 Rampin,* DVM

7

8 * Università degli Studi di Milano, Dipartimento di Patologia Animale, Igiene e

9 Sanità Pubblica Veterinaria, via Caloria 10, 20133 Milano, Italy

$10 \dagger$ Agricultural University of Athens (Greece), Department of Anatomy -

11 Physiology

12 Iera Odos 75, Athens 118 55, Greece

13

14 corresponding author: phone number 00390250318104 Fax number 003902

1550318106 email address: giovanni.manarolla@unimi.it 


\section{Abstract}

2 The causative agents of avian mycobacteriosis in pet birds are rarely identified. The aim

3 of this study is to add information about the etiology of avian mycobacteriosis. The

4 identification of mycobacterium species in 27 cases of avian mycobacteriosis in pet

5 birds was investigated by Polymerase Chain Reaction and sequencing of a rRNA

6 hypervariable region. Avian mycobacteriosis appeared to be an infrequent diagnosis.

7 Interestingly, a few cases of avian mycobacteriosis were recorded in very young birds.

8 The most commonly affected species were the canary (Serinus canarius), the Eurasian

9 goldfinch (Carduelis carduelis) and the Red Siskin (Spinus cucullatus). All but one bird

10 were infected with Mycobacterium genavense. Mycobacterium avium was identified

11 only in one case. 


\section{$1 \quad$ Keywords}

$2 \quad$ Mycobacteria

3 Birds

4

Avian mycobacteriosis

5 Mycobacterium genavense

6 PCR 


\section{Introduction}

2 The causative agents of Avian Mycobacteriosis (AM) in pet birds are rarely

3 identified for lack of specific post mortem findings and for the difficulty in isolating

4 some mycobacterial species, usually referred to as non-culturable mycobacteria (Hoop

5 et al., 1996; Tell et al., 2003). Until a decade ago, most cases of AM were assumed to

6 be caused by Mycobacterium avium-intracellulare complex (MAI). More recently, the

7 use of molecular techniques for species identification brought to light the prominent

8 role of non culturable mycobacteria, primarily Mycobacterium genavense (MG), in

9 several cases of AM in pet birds (Tell et al., 2001). MG is a fastidious organism

10 classified as a non-pigmented, slow-growing mycobacterium (Runyon, 1959; Tortoli,

11 2003), first identified in a human patient with Acquired Immune Deficiency Syndrome

12 (AIDS) (Bottger, 1990; Bottger et al., 1992). This species has since been proven to be

13 pathogenic for numerous avian species (Hoop et al., 1993; Portaels et al., 1996; Hoop et

14 al., 1996; Holsboer Buogo et al., 1997; Manarolla et al., 2007) and a few mammalian

15 species as well (Kiehn et al., 1996; Steiger et al., 2003; Ludwig et al., 2007). The origin

16 of such infection in humans and animals remains obscure (Portaels et al., 1996). MG in

17 pet birds causes a disseminated disease with clinical and histopathological features

18 indistinguishable from AM caused by members of the MAI complex (Portaels et al.,

19 1996; Ramis et al., 1996; Schmidt et al., 2003). The route of infection depends on the

20 mycobacterial species. MAI appear to be ubiquitous in the environment, and they are

21 usually contracted by ingestion. As for MG, the frequent involvement of the gastro-

22 intestinal tract suggests an oral route of infection (Schmidt et al., 2003), though the

23 extensive invasion of the lungs reported in many cases suggest a possible airborne

24 source (Portaels et al., 1996; Manarolla et al., 2007). 
The aim of this study was to determine retrospectively, via Polymerase Chain

2 Reaction (PCR) and sequencing, the mycobacterial species involved in AM cases

3 diagnosed in pet birds in our laboratory over an extended period of time.

4 Materials and Methods

Case Selection: Cases were accessed from January 1987 to September 2007. Of

6 1,961 cases, avian mycobacteriosis was diagnosed in 27 pet birds of varying species

7 from northern Italy. Specimens were presented as intact corpses for necropsy, or as

8 formalin-fixed tissues for histopathology. In all the cases in this study, the diagnosis

9 was based on microscopic findings suggestive of AM and confirmed by Ziehl-Neelsen

10 stain. The year of submission, the species and the affected organs are listed in Table 1.

$11 \quad$ Polymerase chain reaction and sequencing

\section{DNA extraction}

DNA was extracted from formalin-fixed, paraffin-embedded tissues. Three 5- $\mu \mathrm{m}$

14 sections from each of the sampled organs were collected in sterile $1.5 \mathrm{~mL}$ tubes and

15 dewaxed in $1 \mathrm{~mL}$ xylene (VWR BDH Prolabo, Milan, Italy) for $20 \mathrm{~min}$, centrifuged at

$161000 \times g$ for 3 min and washed twice with $100 \%$ ethanol (Merck KGaA, Darmstadt,

17 Germany). DNA was then extracted from the pellet using a DNA minikit (Qiagen,

18 Hilden, Germany) according to the manufacturer's instructions.

The identification of the mycobacterial species was based on the amplification

21 and sequence analysis of a hypervariable region of the 16S rRNA gene. For this

22 purpose, a semi-nested PCR was used. Primers used in the first round PCR were 246

23 (5'-AGAGTTTGATCCTGGCTCAG-3'; nucleotides 8 to 28 of the 16S rRNA gene of

24 Escherichia coli) and 247 (5'-TTTCACGAACAACGCGACAA-3'; nucleotide positions 
1609 to 590 of the E. coli $16 \mathrm{~S}$ rRNA gene) (Hughes et al., 2000). For the second round

2 PCR primers used were p7 (5'-CATGCAAGTCGAACGGAA-3'; nucleotide positions

354 to 71 of the E. coli $16 \mathrm{~S}$ rRNA gene) (Dumonceau et al., 1995 ) and 247.

4 Amplifications were carried out in $50 \mu \mathrm{L}$ PCR buffer (Eppendorf, Hamburg, Germany)

5 containing $1.5 \mathrm{mM} \mathrm{MgCl}_{2}, 20$ pmol each primer, $200 \mu \mathrm{M}$ each dNTP and $1.25 \mathrm{U}$ Taq

6 polymerase (Eppendorf). Incubation conditions for the first reaction consisted of an

7 initial incubation at $95^{\circ} \mathrm{C}$ for $3 \mathrm{~min}$, followed by 35 cycles each of $95^{\circ} \mathrm{C}$ for $35 \mathrm{sec}$,

$8 \quad 64^{\circ} \mathrm{C}$ for $30 \mathrm{sec}$ and $72^{\circ} \mathrm{C}$ for $40 \mathrm{sec}$, then a final incubation at $72^{\circ} \mathrm{C}$ for $8 \mathrm{~min}$.

9 Incubation conditions for the nested reaction consisted of an initial cycle of incubation

10 at $95^{\circ} \mathrm{C}$ for $3 \mathrm{~min}$, followed by 30 cycles each of $95^{\circ} \mathrm{C}$ for $35 \mathrm{sec}, 61^{\circ} \mathrm{C}$ for $35 \mathrm{sec}$ and

$1172^{\circ} \mathrm{C}$ for $40 \mathrm{sec}$, then a final incubation at $72^{\circ} \mathrm{C}$ for $8 \mathrm{~min}$. A $5 \mu \mathrm{l}$ sample of the PCR

12 products was electrophoresed in $2 \%$ agarose (Promega, Milan, Italy) and stained with

13 ethidium bromide (Euroclone, Milan, Italy). Negative controls consisting of the PCR

14 master mixture without genomic DNA and with DNA extracted from negative tissues

15 were included in all PCR amplifications.

\section{Sequencing and sequence analysis}

PCR products of the expected length (555bp) were purified from agarose gel

18 slices using a QIAquick PCR purification kit (Qiagen) and sequenced using an ABI

19 Prism 310 genetic analyser (Applied Biosystems, Foster City, California, USA). The

20 sequences were submitted to the GenBank database. The percentage of similarity with

21 reference sequences was evaluated by BLAST search in the NCBI website. The

22 accession numbers are listed in Table 1.

\section{Results}


The results are listed in Table 1. The birds enrolled in the survey were all pet

2 birds from northern Italy and belonged to 8 different avian species divided as follows: 9

3 canaries (Serinus canarius) (33.3\%), 6 Eurasian goldfinches (Carduelis carduelis)

4 (22.2\%), 5 red siskins (Spinus cucullatus) (18.5\%), 2 Amazona albifrons (7\%), 1

5 Amazona farinosa, 1 greenfinch (Carduelis chloris), 1 Neophema sp, 1 kakariki

6 (Cyanoramphus novaezelandiae), 1 hybrid Carduelis carduelis x Serinus canarius and 1

7 zebra finch (Taenopygia guttata) (3.7\% each). Sixteen birds were from different

8 owners, whereas the other 11 belonged to 3 particular owners as indicated in Table 1. In

98 cases, the age of the bird was not available; 13 birds were adults older than 1 year and

106 birds were younger than 1 year. In 16 cases (59.3\%), there was involvement of the

11 gastrointestinal tract. The respiratory tract was affected in 10 cases (37\%). Two cases of

12 skin lesions were also included.

13 Twenty-six cases (92.9\%) showed non-tubercoloid lesions characterized by focal

14 or extensive sheets of mycobacteria-laden macrophages infiltrating the parenchyma of

15 different organs with variable amounts of necrosis and scattered accumulation of

16 lymphoid cells and heterophils. In these cases, the intracellular acid fast organisms was

17 particularly abundant (Figure 1). Case 2 and case 5 were characterized by typical

18 granulomas with a central necrotic area and a scarcity of mycobacteria surrounded by

19 macrophages and multinucleated giant cells. In cases 4 and 13, PCR did not amplify the

20 hypervariable region of the $16 \mathrm{~S}$ rRNA gene. PCR and sequencing revealed that 23 cases

21 of AM were caused by MG and 1 case by Mycobacterium avium. The percentage of

22 similarity ranged from $99.4 \%$ to $100 \%$. In case 7 , sequencing of the PCR product gave

23 questionable results and was discarded.

\section{Discussion}


Between January 1987 and September 2007, AM was diagnosed histologically

2 in 27 of 1,961 pet birds (1.4\%). This low number probably underestimates the actual

3 cases, since histological examination of dead birds for evident post mortal changes was

4 not frequently performed.

Moreover, some cases might have been overlooked for lack of gross lesions suggestive of AM. Eight different avian species were represented in the survey, albeit

7 most cases were observed in canaries, Eurasian goldfinches and red siskins.

8 Identification of mycobacterial species by molecular techniques was unsuccessful in the

92 cases that yielded no amplification of the hypervariable region of the 16S rRNA gene.

10 As DNA extraction and PCR was repeated twice for these 2 cases, this result can

11 probably be attributed either to scarce quantity of mycobacterial DNA available in

12 paraffin-embedded tissues or to severe DNA damage sustained during processing

13 (Srinivasan et al., 2002).

14 MG was identified in 23 of 24 cases (95.8\%), making it the most prevalent

15 mycobacterial species in this survey. Similar data have been previously observed in pet

16 and aviary birds (Portaels et al., 1996; Hoop et al., 1996; Holsboer Buogo et al., 1997).

17 MG was almost exclusively associated with the non-tuberculoid form of AM and our

18 results sustain that the tuberculoid form is rarely observed in AM of pet birds (Schmidt

19 et al., 2003). We observed typical granulomatous lesions only in cases 2 and 5. In both

20 cases, the granulomas affected the periocular region of two parrots. This lesion site has

21 been previously described in numerous avian species affected by AM (Tell et al., 2001).

22 It is worth noting that case 1 dated to 1989. This result revealed MG had

23 infected an avian host one year before its first identification in a human AIDS patient

24 (Bottger, 1990; Bottger et al., 1992). It is particularly noteworthy that MG was 
1 identified in more birds from the same owners (Table 1). Although previous reports

2 supported a limited contagiousness of MG (Hoop et al., 1993; Manarolla et al., 2007), in

3 these cases we cannot exclude an animal-to-animal spread of the infection among

$4 \quad$ several birds kept in close contact. Mycobacterium avium was identified only in case 20. This result sustains

6 previous European reports where this mycobacterial species is referred to as not

7 predominant in AM of pet birds (Portaels et al., 1996; Hoop et al., 1996; Holsboer

8 Buogo et al., 1997). On the contrary, Mycobacterium avium and Mycobacterium

9 intracellulare are commonly identified in aviaries at zoos (Schrenzel et al., 2008).

10 Further studies seem necessary to find out whether regional differences in speciation

11 exist.

12 Histological appearance of the lesions in this case overlapped the pathological

13 features found in most MG infections as previously reported (Hoop et al., 1993; Portaels

14 et al., 1996; Manarolla et al., 2007). In 10 cases (37\%) there was involvement of the

15 respiratory tract. Given that the lung is an uncommon site for mycobacterial lesions in

16 birds, this finding was already observed in previous reports (Portaels et al., 1996;

17 Manarolla et al., 2007) and suggests that an airborne source of infection must be

18 considered in AM of pet birds. We can speculate that the routine cleaning procedures of

19 the cages where AM-infected birds live could aerosolise mycobacteria from infected

20 feces, which remain the principal source of shedding and infection for other birds (Tell

21 et al., 2001). Interestingly, 6 of the 19 birds of known age (31.6\%) were younger than 1

22 year. This result confirms that, although AM is more frequently observed in adult birds

23 as a consequence of the chronic nature of the disease, it must be considered as a

24 possible diagnosis in juvenile birds that have died without specific findings. A vertical 
1 route of transmission cannot be excluded, though it is believed to be unlikely (Tell et

2 al., 2001). Molecular identification is the most accurate approach for making an

3 etiological diagnosis because these micro-organisms are difficult to isolate.

4 Unfortunately, application of this technique to paraffin-embedded material in

5 retrospective studies can be unsuccessful.

6 The results of this survey suggest MG must be suspected over other

7 mycobacterial species as a possible culprit in cases of AM diagnosed histologically in

8 companion birds. The origin of such infections could not be identified, and it is also

9 uncertain whether immunosuppression plays a role in $\mathrm{AM}$ as it does in the human

10 counterpart. The environment is considered the natural reservoir of non tuberculous

11 mycobacteria (Bottger, 1994; Tortoli, 2004; Schrenzel et al., 2007). Nevertheless, it has

12 been hypothesized the birds to be the only identified potential reservoir for MG (Tortoli,

13 2003), and, though limited, the results of this survey sustain this hypothesis.

14 Consequently, further studies aimed at clarifying the epidemiological mechanisms that

15 MG uses to infect companion birds seem necessary.

16 MG is pathogenic for people immunocompromised by either HIV or by

17 iatrogenic immuno-suppression (Boian et al., 1997; Tortoli, 2004). AM is unlikely to

18 represent a significant risk for healthy humans. However, the potential for zoonotic

19 disease must be considered, especially if persons who are immunocompromised are in

20 contact with an infected bird (Bottger, 1994; Boian et al., 1997; Lennox, 2007)

21 Unfortunately, no data about the health status of the bird owners were available for this

22 survey; however, it might be investigated whether the anamnestic data of human

23 patients with MG infections include previous contact with companion birds. 
This work was supported by grants from Regione Lombardia (Italy).

We thank Dr Enrico Tortoli for providing a Mycobacterium genavense strain highly appreciated. 


\section{References}

1. Boian, M., Avaniss-Aghajani, E., Walker, R., Aronson, T., Tran, T., Glover, N., Berlin, O.G.W., Woods, L., Brunk, C., Li, J.L., Froman, S., Holtzman, A., 1997. Identification of Mycobacterium genavense in intestinal tissue from a parakeet using two polymerase chain reaction methods: Are pets a reservoir of infection in AIDS patients? (Letter). AIDS.11, 255-226.

2. Bottger, E.C., 1990. Infection with a novel, unidentified mycobacterium. N. Engl. J. Med. 323, 109-113.

3. Bottger, E.C., Teske, A., Kirschner, P., Bost, S., Chang, H.R., Beer, V., Hirschel, B., 1992. Disseminated "Mycobacterium genavense" infection in patients with AIDS. Lancet. 340, 76-80.

4. Bottger, E.C., 1994. Mycobacterium genavense: an emerging pathogen. Eur. J. Clin. Microbiol. Infect. Dis.13, 932-936.

5. Dumonceau, J. M., Fonteyne, P. A., Realini, L., van Gossum, A., van vVoren, J. P., Portaels F., 1995. Species-specific Mycobacterium genavense DNA in intestinal tissues of individuals not infected with Human Immunodeficiency Virus. J. Clin 33, 2514-2515.

6. Holsboer Buogo, C., Bacciarini, L., Robert, N., Bodmer, T., Nicolet, T., 1997. Vorkommen von Mycobacterium genavense bei Vögeln. Schweiz. Arch. Tierheilkd. 139, 397-402.

7. Hoop, R.K., Bottger, E.C., Ossent, P., Salfinger, M., 1993. Mycobacteriosis Due to Mycobacterium genavense in Six Pet Birds. J. Clin. Microbiol. 31, 990-993. 
8. Hoop, R.K., Bottger, E., Pfyffer, G.E., 1996. Etiological agents of mycobacterioses in pet birds between 1986 and 1995. J. Clin. Microbiol. 34, 991-992.

9. Hughes M. M. James G., Ball N., Scally M., Malik, R. Wigney D. I., Martin P., Chen S., Mitchell D., Love D. N., 2000. Identification by 16S rRNA gene analyses of a potential novel Mycobacterial species as an etiological agent of canine leproid granuloma syndrome. J. clin. Microbiol. 38, 953-959.

10. Kiehn, T.E., Hoefer, H., Bottger, E.C., Ross, R., Wong, M., Edwards, F., Antinoff, N., Armstrong, D., 1996. Mycobacterium genavense infections in pet animals. J. Clin. Microbiol. 34, 1840-1842.

11. Lennox A.M., 2007. Mycobacteriosis in companion psittacine birds: A review. Journal of Avian Medicine and Surgery. 21, 181-187.

12. Ludwig, E., Reischl, U., Janik, D., Hermanns, W. Granulomatous pneumonia caused by Mycobacterium genavense in a dwarf rabbit (Oryctolagus cuniculus). In: abstract of the $25^{\text {th }}$ Annual Meeting of The European Society of Veterinary Pathology, Munich, Germany; 2007 Aug $28^{\text {th }}-$ Sept $1^{\text {st. }} ;$ p.138. Munich, Germany: The European Society of Veterinary Pathology.

13. Manarolla, G., Liandris, E., Pisoni, G., Moroni, P., Piccinini, R., Rampin, T., 2007. Mycobacterium genavense and avian polyomavirus co-infection in a European goldfinch (Carduelis carduelis). Avian Pathol. 36, 423-426.

14. Portaels, F., Realini, L., Bauwens, L., Hirschel, B., Meyers, W.M., de Meurichy, W.,1996. Mycobacteriosis caused by Mycobacterium genavense in birds kept in a zoo: 11-year survey. J. Clin. Microbiol. 34, 319-323. 
15. Ramis., A., Ferrer, L., Aranaz, A., Liebana, E., Mateos, A., Dominguez, L., Pascual, C., Fdez-Garayazabal, J., Collins, M.D., 1996. Mycobacterium genavense infection in canaries. Avian Dis. 40, 246-251.

16. Runyon, E.H., 1959. Anonymous mycobacteria in pulmonary disease. Med. Clin. North Am. 43, 273-290.

17. Schmidt, R.E., Reavill, D.R., Phalen, D.N., 2003. Liver. In: Pathology of Pet and Aviary Birds: Ames: Iowa State Press, pp. 70-77.

18. Schrenzel, M., Nicolas, M., Witte, C., Papendick, R., Tucker, T., Keener, L., Sutherland-Smith, M., Lamberski, N., Orndorff, D., Heckard, D., Witman, P., Mace, M., Rimlinger, D., Reed, S., Rideout, B., 2008. Molecular epidemiology of Mycobacterium avium subsp. avium and Mycobacterium intracellulare in captive birds. Vet. Microbiol. 126, 122-131.

19. Srinivasan, M., Sedmak, D., Jewell, S., 2002. Effect of Fixatives and Tissue Processing on the Content and Integrity of Nucleic Acids. Am. J. Pathol. 161, 1961-1971.

20. Steiger, K., Ellenberger, C., Schüppel, K.F., Richter, E., Schmerbach, K., Krautwald-Junghanns, M.E., Wünnemann. K., Eulenberger, K., Schoon, H.A., 2003. Ungewohnliche Mykobakterien-Infektionen bei Haus- und Zootieren: eine Kasuistik unter besonderer Berucksichtigung der Pathologie. Dtsch. Tierarztl. Wochenschr. 110, 382-388

21. Tell, L.A., Woods, L., Cromie, R.L., 2001. Mycobacteriosis in birds. Rev. Sci. Tech. Ser. Sci. Hum. (International Office of Epizootics). 20, 180-203.

22. Tell L.A., Foley J., Needham M.L., Walker R.L., 2003. Diagnosis of avian mycobacteriosis: comparison of culture, acid-fast stains and polymerase chain 
reaction for the identification of Mycobacterium avium in experimental inoculated japanese quail (Coturnix coturnix japonica)." Avian Dis. 47, 444-452.

23. Tortoli, E., 2003. Impact of Genotypic Studies on Mycobacterial Taxonomy: the New Mycobacteria of the 1990s. Clin. Microbiol. Rev.16, 319-354.

24. Tortoli, E., 2004. Clinical Features of Infections Caused by New Nontuberculous Mycobacteria, Part I*. Clin. Microbiol. Newsl. 26, 89-95. 
Table 1 - material and results of the survey

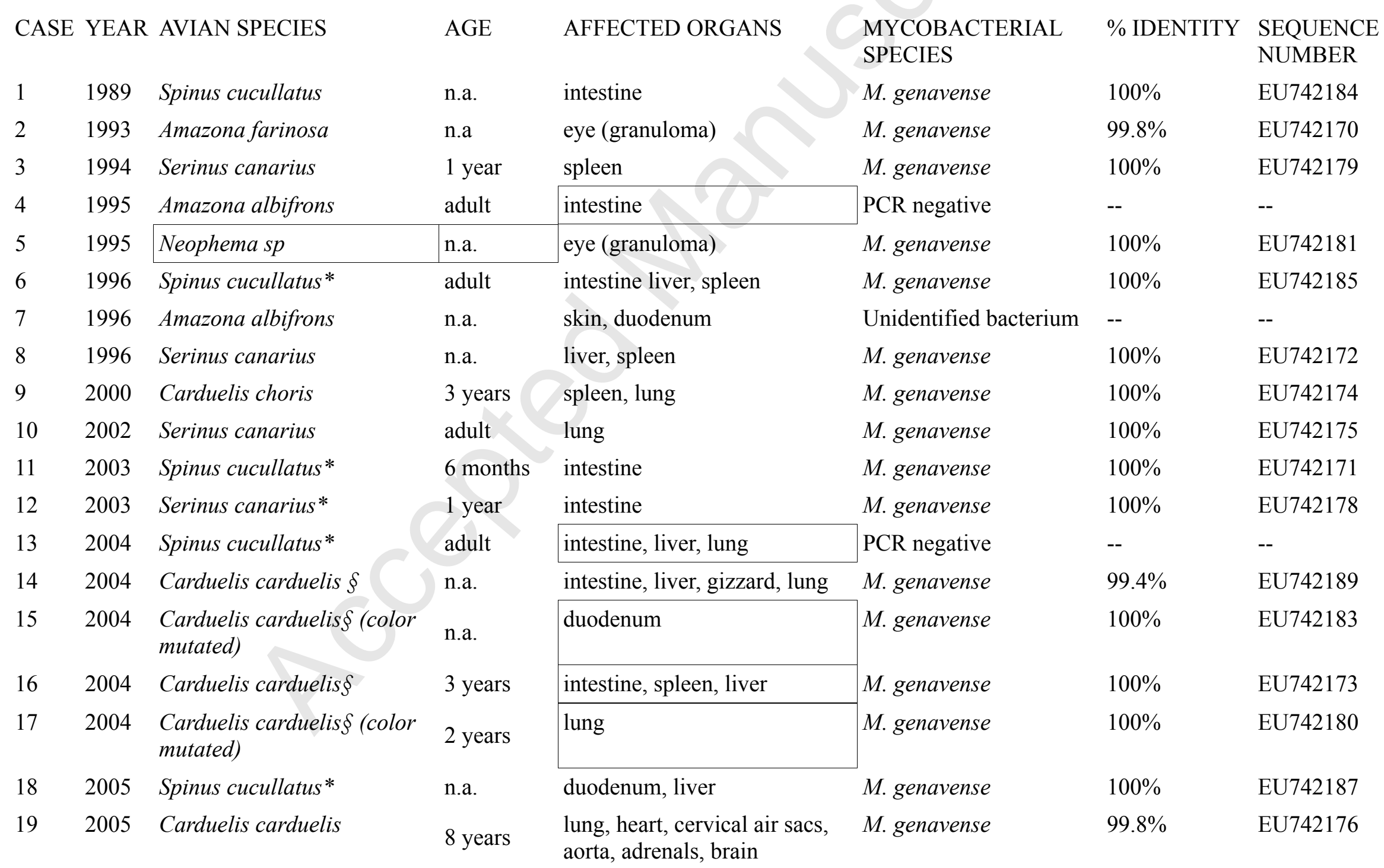




\begin{tabular}{|c|c|c|c|c|c|c|c|}
\hline 20 & 2005 & Carduelis carduelis & 2 years & intestine, liver, spleen, lung & M. avium & $100 \%$ & EU742166 \\
\hline 21 & 2005 & Serinus canarius & 1.5 year & spleen & M. genavense & $100 \%$ & EU742182 \\
\hline 22 & 2005 & $\begin{array}{l}\text { Hybrid: Carduelis carduelis } \\
x \text { Serinus canarius }\end{array}$ & 1 year & intestine, liver, splee & M. genavense & $100 \%$ & EU742177 \\
\hline 23 & 2006 & Serinus canarius $^{\circ}$ & adult & spleen & M. genavense & $100 \%$ & EU742168 \\
\hline 24 & 2007 & Serinus canarius $^{\circ}$ & 4 years & lung & M. genavense & $100 \%$ & EU742188 \\
\hline 25 & 2007 & $\begin{array}{l}\text { Cyanoramphus } \\
\text { novaezelandiae }\end{array}$ & 12 years & intestine, liver & M. genavense & $100 \%$ & EU742167 \\
\hline 26 & 2007 & Taeniopygia guttata & 1 year & gizzard, intestine, liver, spleen & M. genavense & $100 \%$ & EU742169 \\
\hline 27 & 2007 & Serinus canarius & 1 year & lung, air sacs & M. genavense & $100 \%$ & EU742186 \\
\hline
\end{tabular}

n.a. not available

$\S, *$, identifying birds from a same owner 


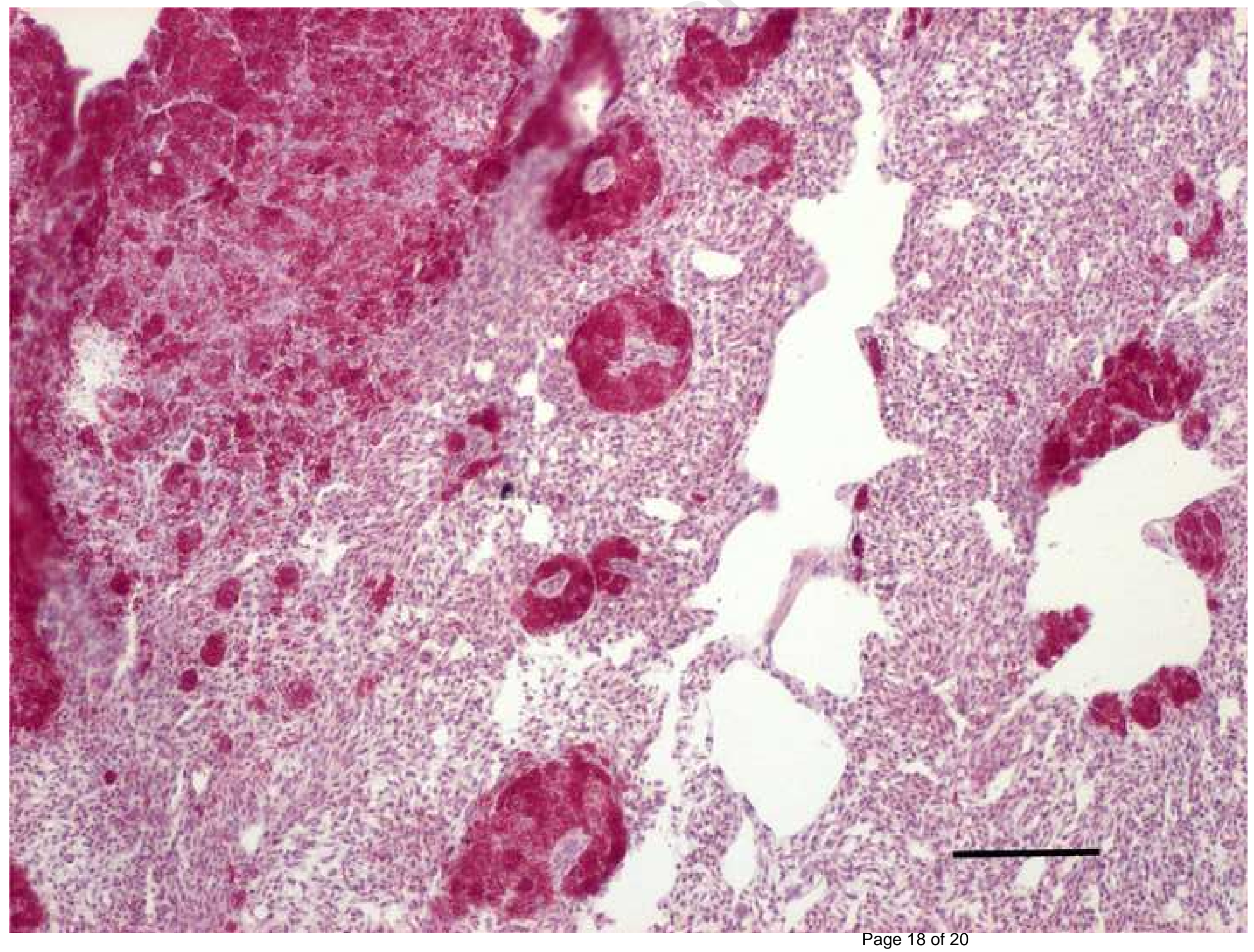

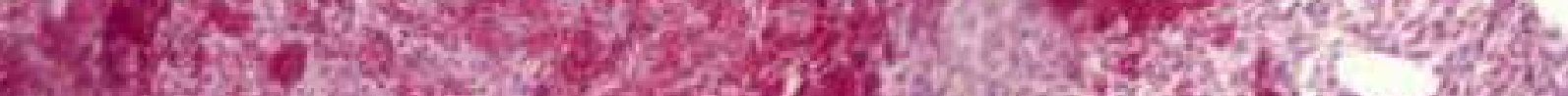

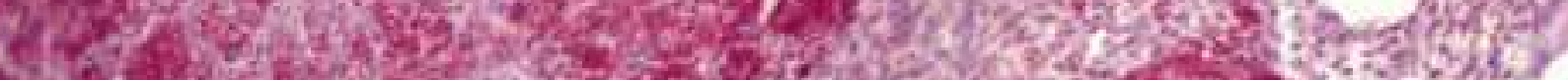

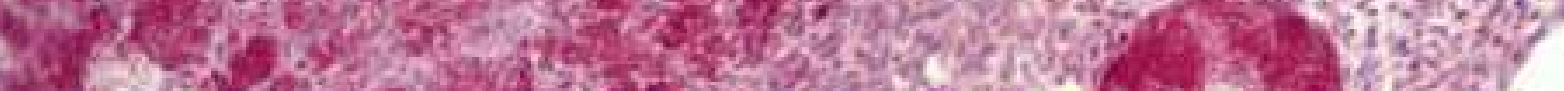

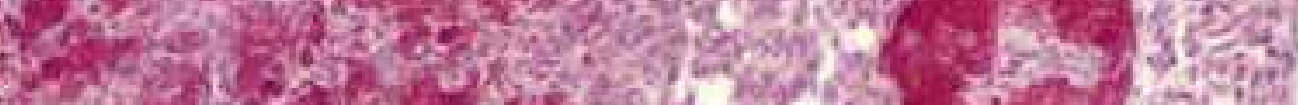

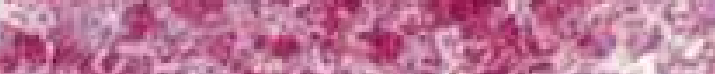
tor

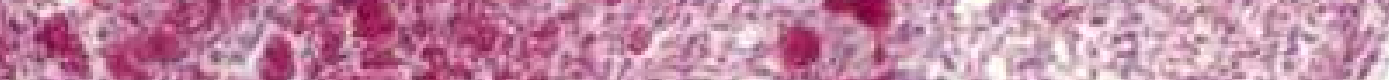

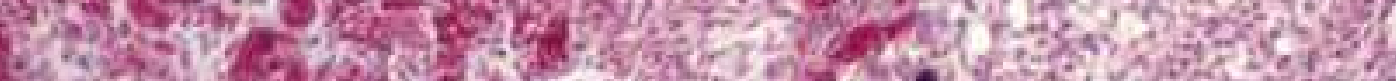

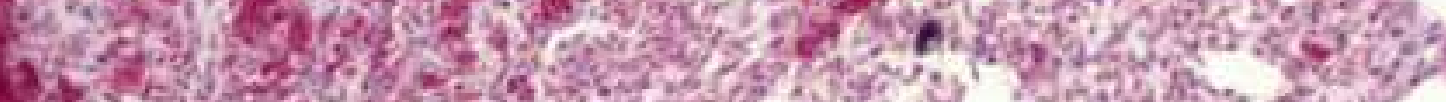

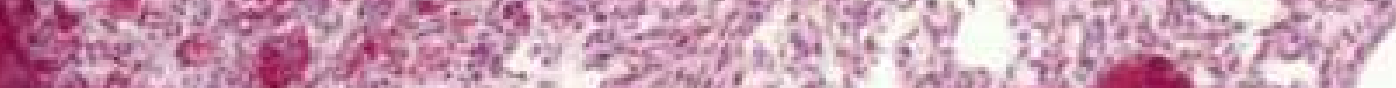

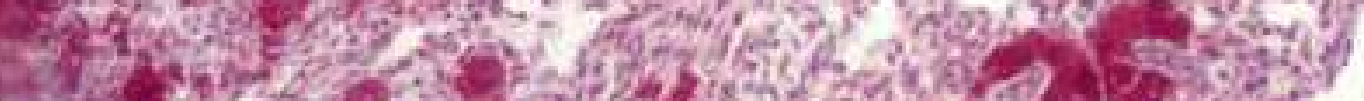

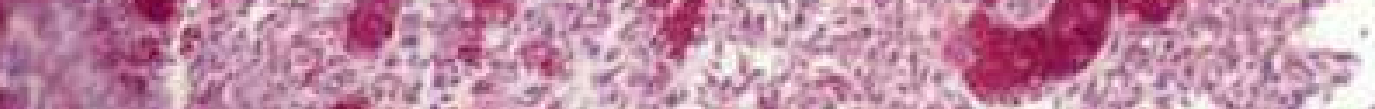

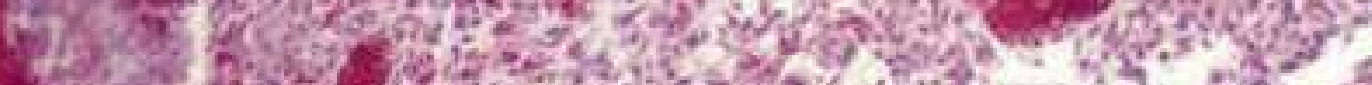

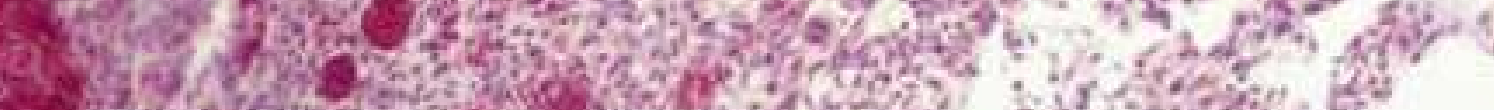

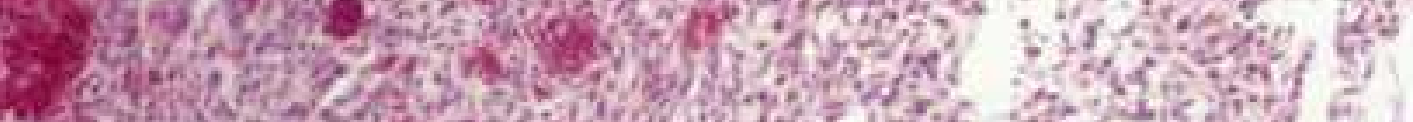

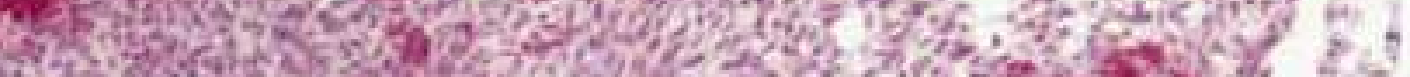

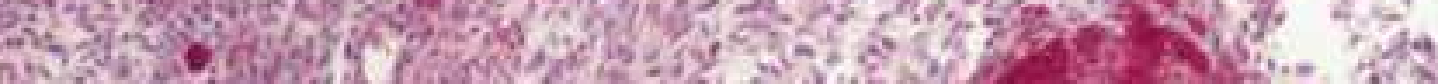

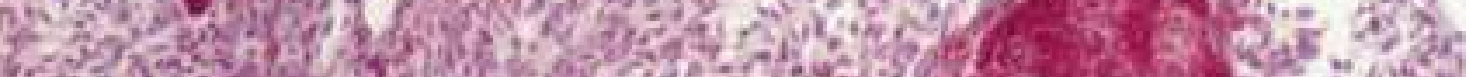
1.

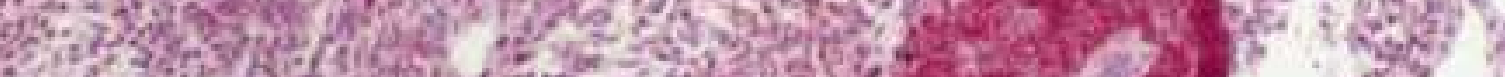

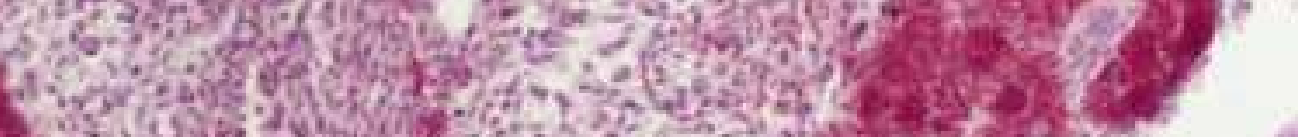

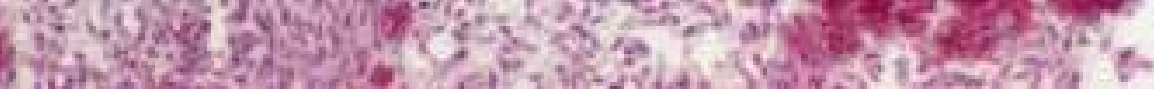




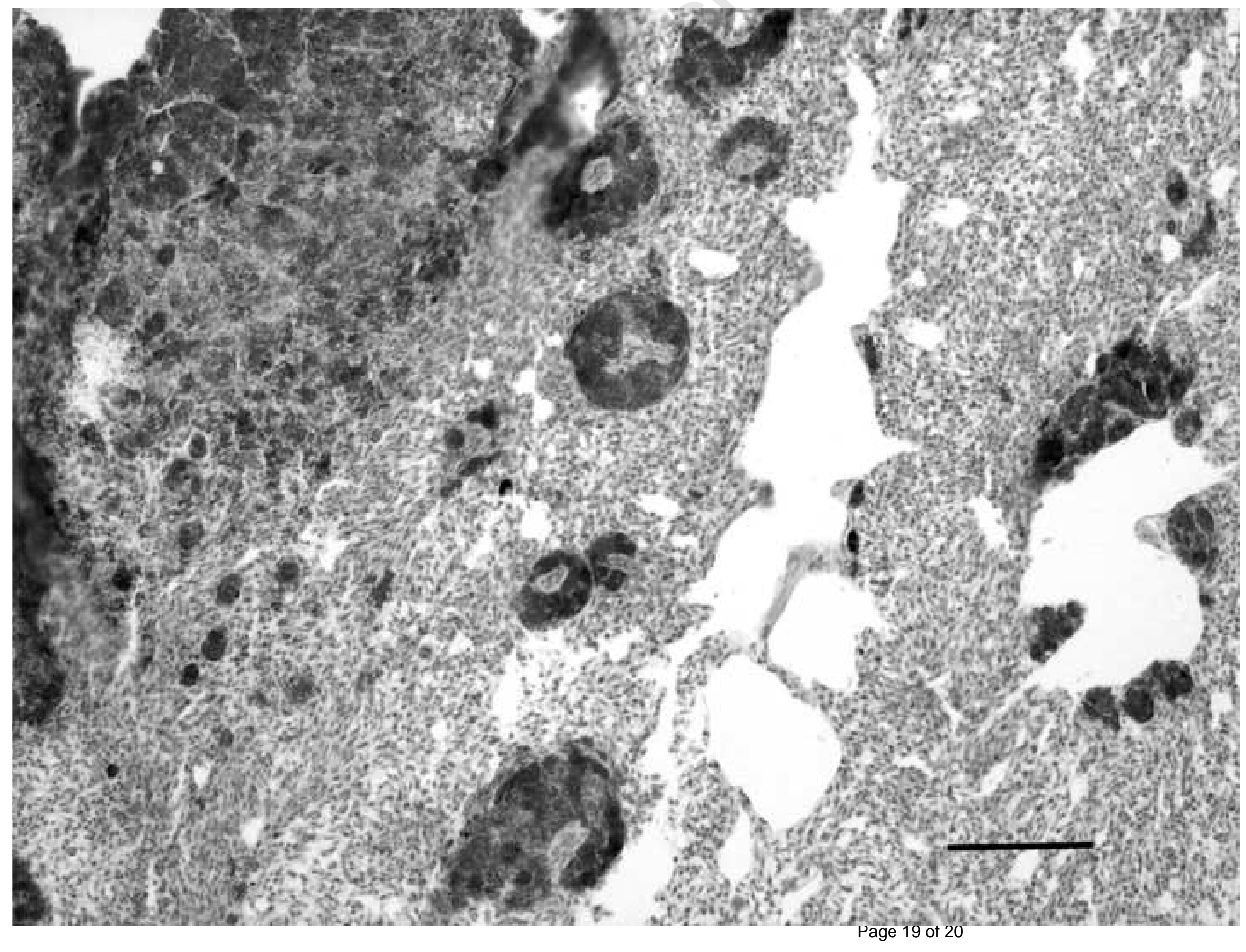

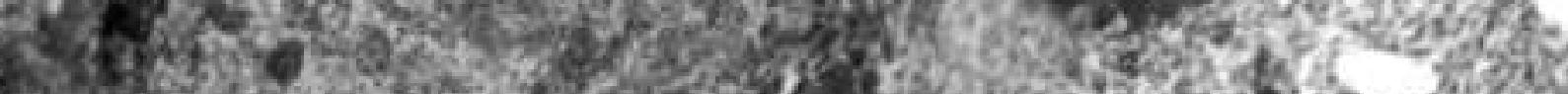
d.

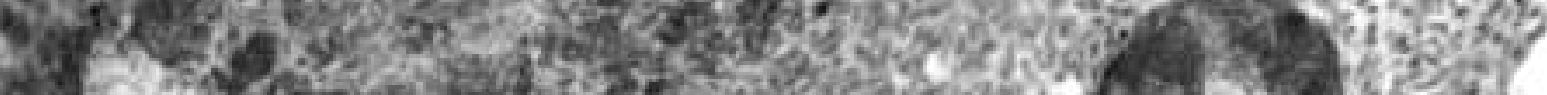

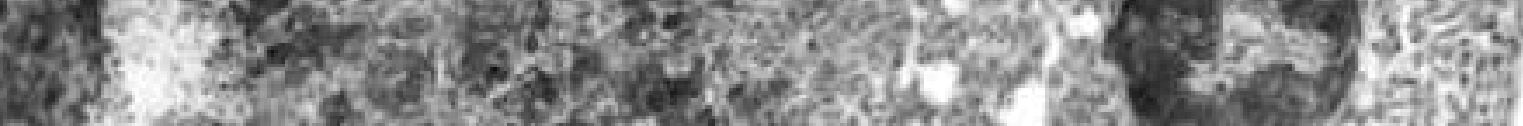

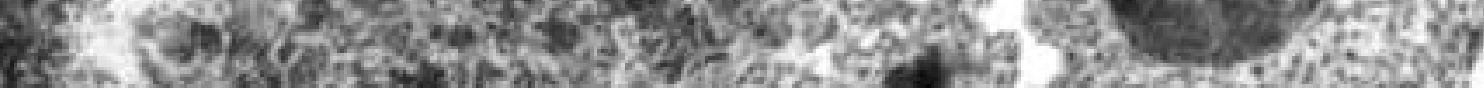

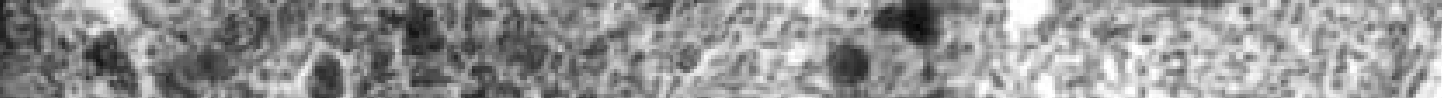

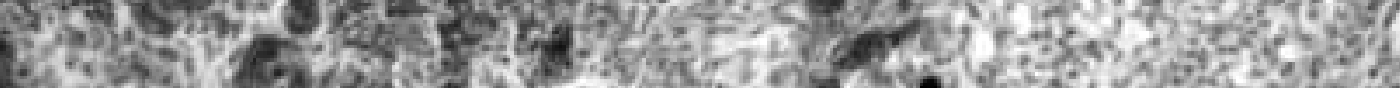

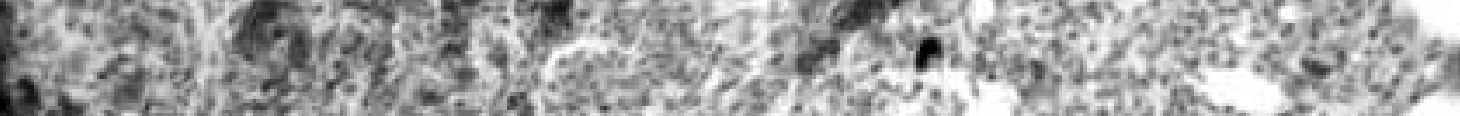

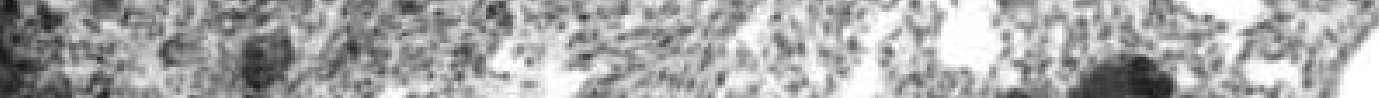

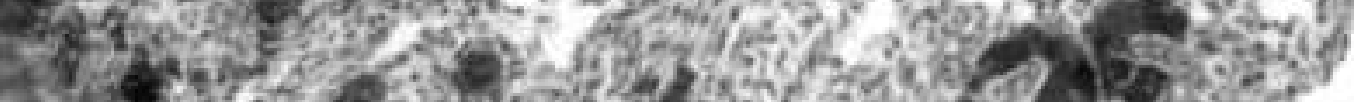
Q3) 3 a

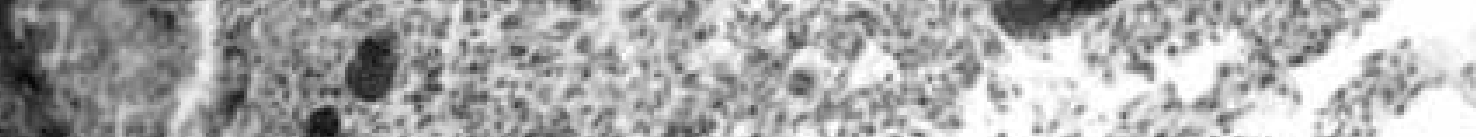

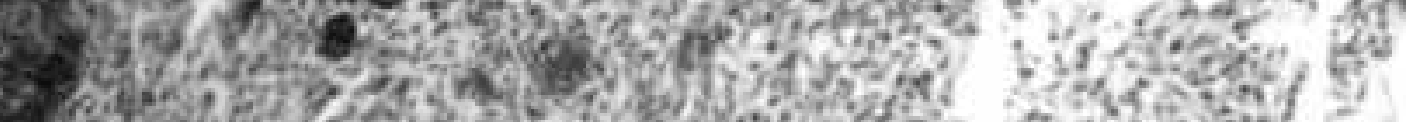

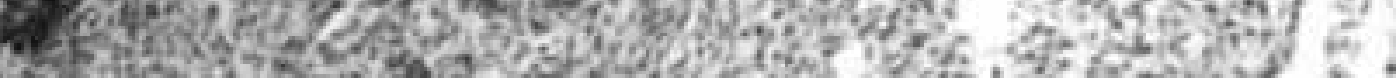

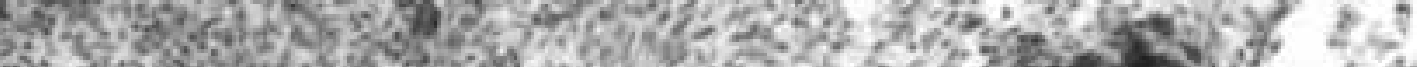

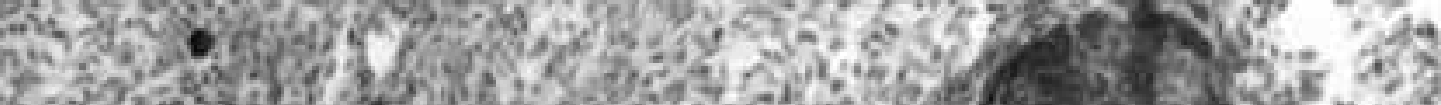

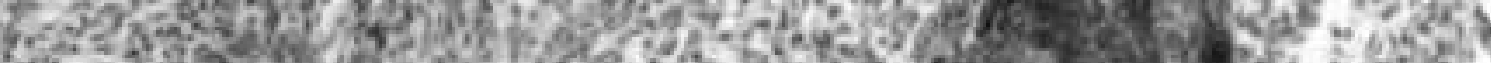

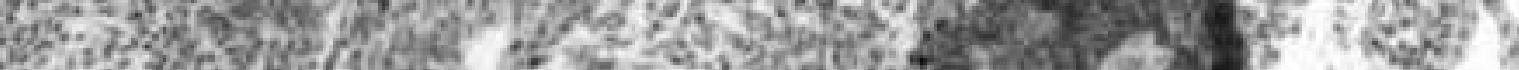

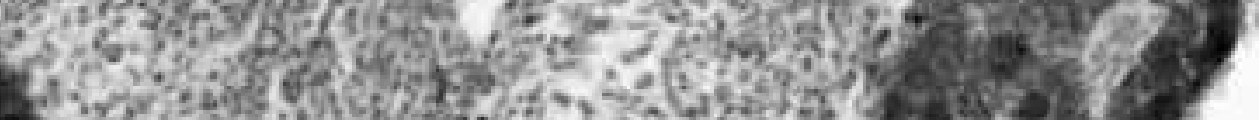

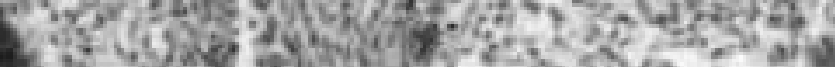

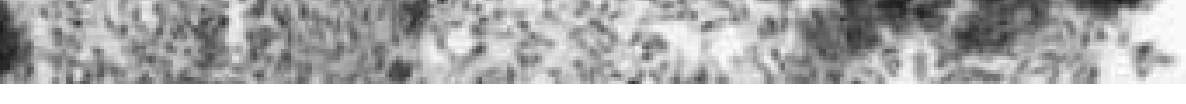

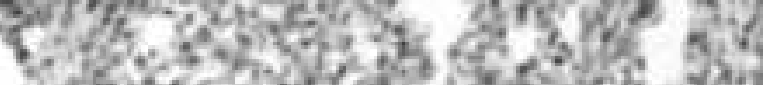

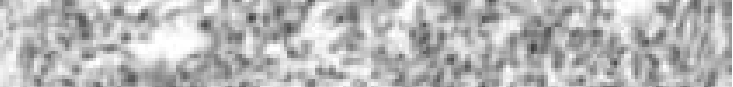

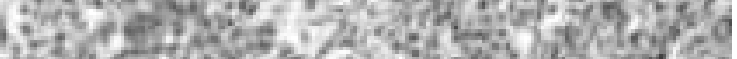

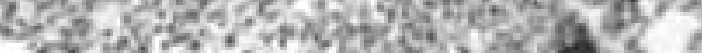
(x)

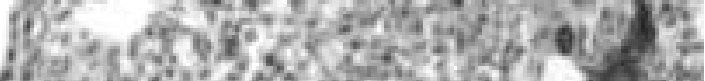
Q.5.

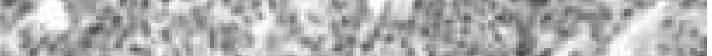

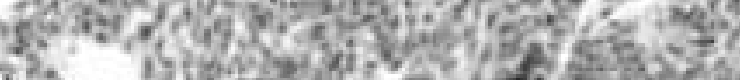

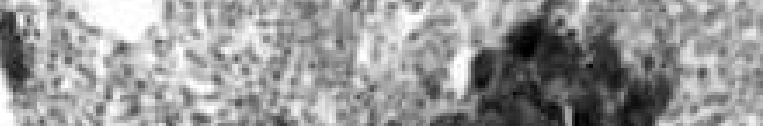

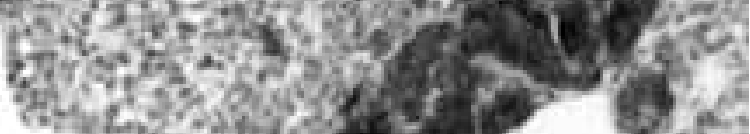

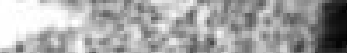

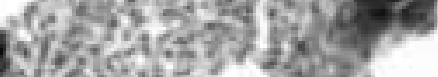
$+x^{2}$ 28: 4.3. 372 394 80 n.t.

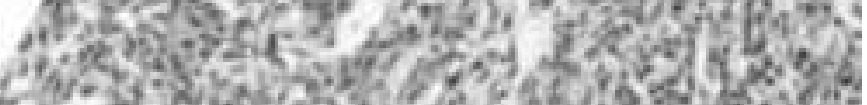
. 50 - he of

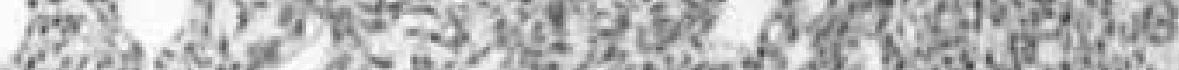

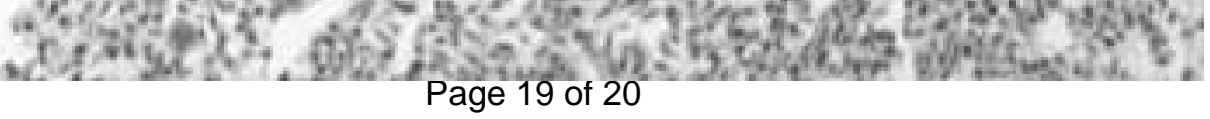


Figure 1. Section of lung of a European goldfinch showing multifocal lesions consisting of macrophagic aggregates with numerous intracytoplasmic acid fast bacilli. Ziehl-Neelsen stain. Bar $=150 \mu \mathrm{m}$. 